\title{
IMPLEMENTATION OF SINGLE-LEVEL, FIXED ROTATION MULTILEVEL, AND INDEPENDENT ROTATION MULTILEVEL SAVONIUS WIND TURBINE
}

\author{
Bagus Arthaya \\ Department of Mechatronics \\ Parahyangan Catholic University \\ Bandung, West Java, Indonesia
}

\author{
Levin Halim \\ Department of Mechatronics \\ Parahyangan Catholic University \\ Bandung, West Java, Indonesia
}

\author{
Marvin Trisakti \\ Department of Mechatronics \\ Parahyangan Catholic University \\ Bandung, West Java, Indonesia
}

\begin{abstract}
Wind energy has many advantages compare to fossil fuel like it doesn't produce air pollution. However, to utilize the wind energy to electricity, the wind turbine is necessary to transfer the wind energy to angular energy so that the wind energy can be transform to electric energy using generator. This paper aims to analyze the design and implementation comparison between single-level and multi-level Savonius wind turbine. The parameters included in the design and implementation include the size of the blade and how the turbine works. In this research, there are three Savonius wind turbine designs to be tested, such as single-level Savonius wind turbine, multi-level Savonius wind turbine with a fixed rotational axis, and multi-level Savonius wind turbine with an independent rotational axis. The reviewed Savonius wind turbine's measurement performed on wind speed with the range of $3 \mathrm{~m} / \mathrm{s}$ to $4.2 \mathrm{~m} / \mathrm{s}$. Based on the measurement result, leveled Savonius wind turbine with a fixed rotational axis has the highest performance. Multi-level Savonius wind turbine with fixed rotational axis has the highest performance with the value of rotational speed average $273,06 \mathrm{rpm}$, torque average $0,434 \mathrm{Nm}$, and power average $12,72 \mathrm{Watt}$
\end{abstract}

Keywords-Design, Implementation, Angular Speed, Torque, Power

\section{INTRODUCTION}

Fossil fuel consumption is still one of the most significant issues because it grows faster than the population growth[1][2]. Especially in third world country, fossil fuel consumption increase $1.5 \%$ each year[3]. Indonesia itself, electricity consumption still depends on fossil fuel, especially coal. Even though the coal resources in Indonesia are massive, but over time the resources will become rare. Based on the geographic condition, Indonesia has a high potential to developed, such as solar energy, wind energy, micro-hydro, and biomass[4].
Wind energy has many advantages compare to fossil fuel like it doesn't produce air pollution, greenhouse effect, and environmental friendly[5]. Besides all of those advantages, the utilization of wind turbines in 2018 only took $0.22 \%$ of Indonesia's energy consumption[6]. The reason is that the wind speed in Indonesia, ranging between $2 \mathrm{~m} / \mathrm{s}$ to $6 \mathrm{~m} / \mathrm{s}[7]$, which is categorized as low wind speed based on the Beaufort scale[8]. Because of that, the wind speed can't fulfill the wind speed needs for a propeller wind turbine or horizontal wind turbine starting to rotate that is $8 \mathrm{~m} / \mathrm{s}$ [9]. The research at Blitar, East Java, has the value of wind speed equal to $3 \mathrm{~m} / \mathrm{s}$ until $4.2 \mathrm{~m} / \mathrm{s}$. Based on that wind speed condition, this research will use the Savonius wind turbine because it can rotate at low wind speed and has a higher power coefficient[11]. The researcher analyzes the power coefficient on simulation and theoretical calculation before on paper[12], and the error value between simulation and theoretical calculation equal to $0.123 \%$, so this research will continuing the works by comparing the angular speed, torque, and power based on the measurement of the implementation of Savonius wind turbine.

This paper discussed the design and implementation of the Savonius wind turbine. There is 3 reviewed Savonius wind turbine design that will be measured, such as single-level Savonius wind turbine, multi-level Savonius wind turbine with the fixed rotational axis, and multi-level Savonius wind turbine with the independent rotational axis as shown in Figure 1, Figure 2, and Figure 3. 


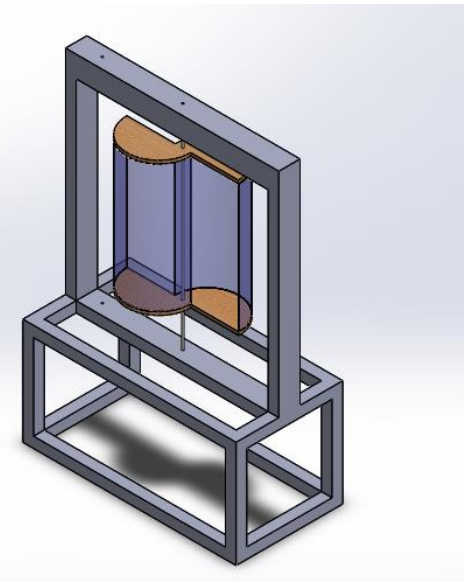

Fig. 1. Single-level Savonius Wind Turbine Design

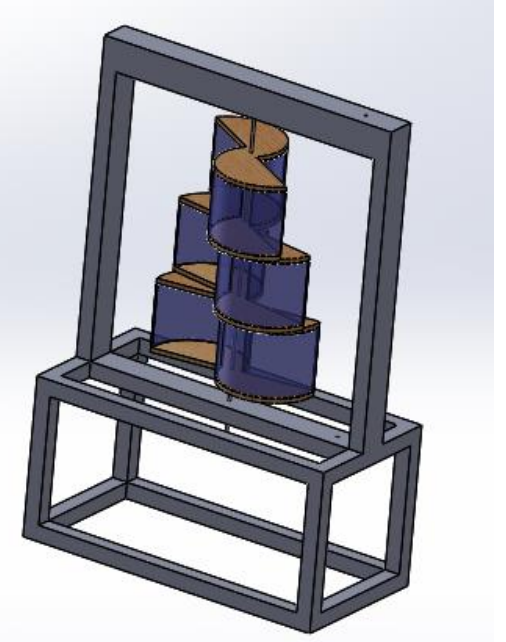

Fig. 2. Multi-level Savonius Wind Turbine with Fixed Rotational Axis Design

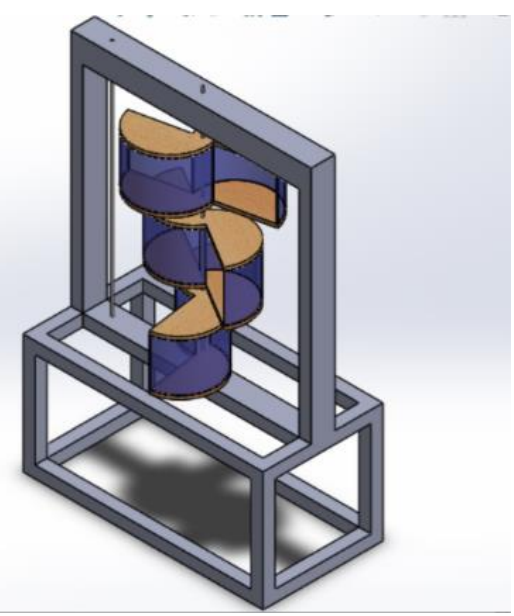

Fig. 3. Multi-level Savonius Wind Turbine with Independent Rotational Axis Design

\section{METHODOLOGY}

The methodology used in this paper is shown in Figure 4.

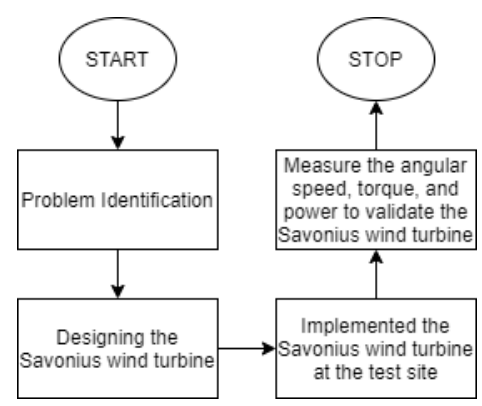

Fig. 4. Methodology Flowchart

The first step of this research is to identify the research problem. This research aims to identify the Savionus wind turbine performance based on the implementation measurement with the parameters such as rotational speed, torque, and power.

The next step is designing the structure of three Savonius wind turbines that will be reviewed. After that, the Savoniniuw wind turbine builds based on the design. The final step compares the performance between three Savonius wind turbine structures based on angular speed, torque, and power parameters.

\section{A. Work Principles and Parameters Design of Savonius Wind Turbine}

Finnish engineer Sigurd Savionus invent the Savionus wind turbine in 1922[13]. The Savionus wind turbine's blade design is like the letter $\mathrm{S}$ and the number of the blade can be modified depends on the wind speed[11].

Savionus wind turbine works with the principles of the differences of the wind forces between each blade. The concave part on the blade caught the wind force, so the wind turbine's vertical shaft can rotate. Meanwhile, the air that hits the convex portion deflected sideways around it. These principles can be shown in Figure 5.[11].
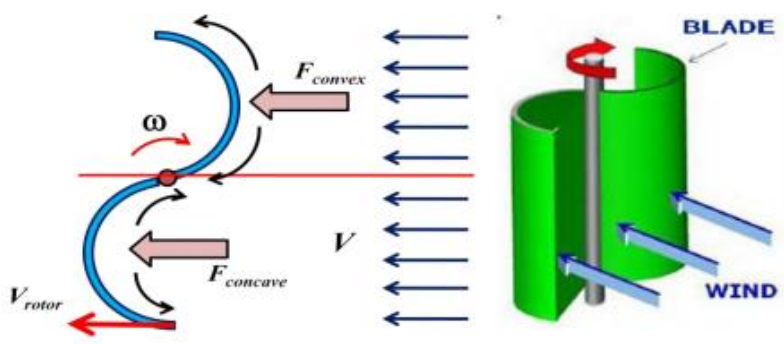

Fig. 5. Wind Force on Savonius Wind Turbine [10] 
Because of the differences wind force on each part of the blade, it forced the rotor to rotate in line as the wind direction hit the concave portion of the edge.

The design of a Savonius wind turbine has several parameters, such as:

- $\quad$ Blade Radius (r)

- $\quad$ Plate Thickness (h)

- $\quad$ Blade Height $(\mathrm{H})$

- $\quad$ Shaft Diameter (D)

- $\quad$ Blade Diameter (Do)

These parameters will be validated based on the angular speed, torque, and power values of each Savonius wind turbine.

\section{B. Designing the Savonius Wind Turbine}

In this research, the design consists of a single-level Savonius wind turbine, a multi-level Savonius wind turbine with a fixed rotational axis, and a multi-level Savonius wind turbine with an independent rotational axis. Figure 6 shows the parameters of the blade. Table 1. shows the specification of the single-level Savonius wind turbine blade parameters.

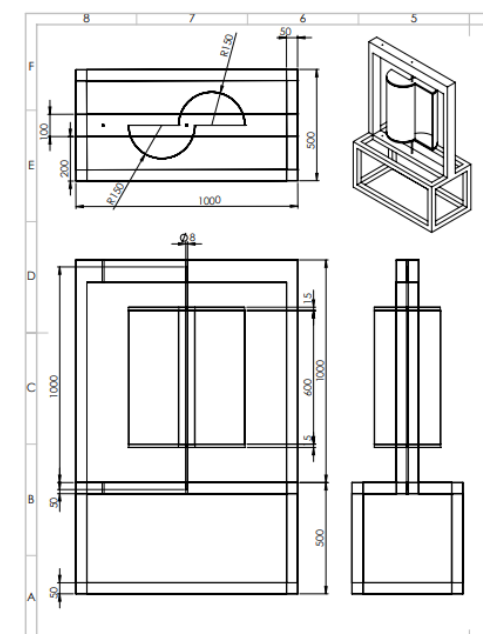

Fig. 6. Blade Design of Single-level Savonius Wind Turbine

Table -1 Parameters of Single-level Savonius Wind Turbine

\begin{tabular}{|c|c|c|}
\hline Variable & Parameter & Size \\
\hline $\mathrm{r}$ & Blade Radius & $145 \mathrm{~mm}$ \\
\hline $\mathrm{h}$ & Plate Thickness & $15 \mathrm{~mm}$ \\
\hline $\mathrm{H}$ & Blade Height & $600 \mathrm{~mm}$ \\
\hline $\mathrm{D}$ & Shaft Diameter & $8 \mathrm{~mm}$ \\
\hline Do & Blade Diameter & $600 \mathrm{~mm}$ \\
\hline
\end{tabular}

Figure 7 shows the multi-level Savonius wind turbine with fixed rotational axis design and the blade design. Meanwhile,
Table 2 shows the multi-level Savonius wind turbine's specification with fixed rotational axis blade parameters.

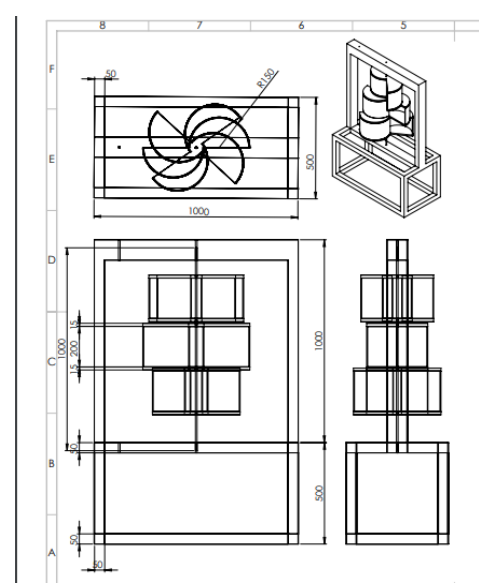

Fig. 7. Multi-level Savonius Wind Turbine with Fixed Rotational Axis Blade Design

Table -2 Parameters of Single-level Savonius Wind Turbine

\begin{tabular}{|c|c|c|}
\hline Variable & Parameter & Size \\
\hline $\mathrm{r}$ & Blade Radius & $145 \mathrm{~mm}$ \\
\hline $\mathrm{h}$ & Plate Thickness & $15 \mathrm{~mm}$ \\
\hline $\mathrm{H}$ & Blade Height & $200 \mathrm{~mm}$ \\
\hline $\mathrm{D}$ & Shaft Diameter & $8 \mathrm{~mm}$ \\
\hline Do & Blade Diameter & $600 \mathrm{~mm}$ \\
\hline & Angle Between Levels & $30^{\circ}$ \\
\hline
\end{tabular}

Figure 8 shows the multi-level Savonius wind turbine with independent rotational axis design and the blade design.

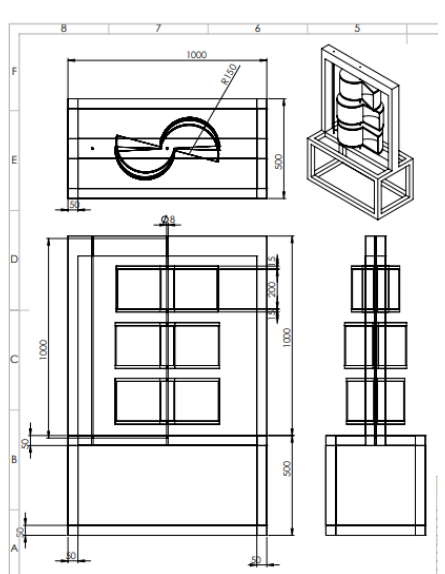

Fig. 8. Multilevel Savonius Wind Turbine with Independent Rotational Axis Blade Design

The component that is used on the multi-level Savonius wind turbine with an independent rotational axis is shown in Figure 9. 


\section{International Journal of Engineering Applied Sciences and Technology, 2020 \\ Vol. 5, Issue 6, ISSN No. 2455-2143, Pages 1-7 \\ Published Online October 2020 in IJEAST (http://www.ijeast.com)}

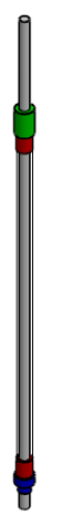

Fig. 9. Multi-level Savonius wind turbine with an independent rotational axis

The red part of Figure 9. represents the roller bearings is in the hollow shaft, while the blue part is the connector adapter shaft, which has a function as a holder so that the blade does not fall down and as a connection between the blade and the shaft. On the other hand, the green part is the timing pulley attached to the shaft turbine with a measuring shaft so that the rotation of the turbine can be channeled on the measuring shaft.

Table 3 shows the size of every parameter from the multi-level Savonius wind turbine with an independent rotational axis blade design.

Table -3 Parameters of Single-level Savonius Wind Turbine

\begin{tabular}{|c|c|c|}
\hline Variable & Parameter & Size \\
\hline R & Blade Radius & $145 \mathrm{~mm}$ \\
\hline H & Plate Thickness & $15 \mathrm{~mm}$ \\
\hline H & Blade Height & $200 \mathrm{~mm}$ \\
\hline D & Shaft Diameter & $8 \mathrm{~mm}$ \\
\hline Do & Blade Diameter & $600 \mathrm{~mm}$ \\
\hline X & Spacing Between Levels & $20 \mathrm{~mm}$ \\
\hline
\end{tabular}

Parameters are shown in Table 1, Table 2, and Table 3 used as a reference to build the blade of each Savonius wind turbine on implementation.

\section{EXPERIMENT AND RESULT}

\section{A. Implementation of Single-level Savonius Wind Turbine}

Figures 10 and 11 show the result of the blade and implementation of a single-level Savonius wind turbine.

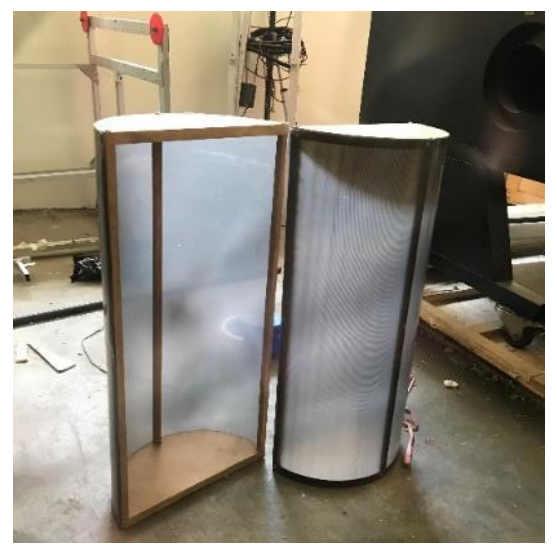

Fig. 10. Single-level Savonius Wind Turbine Blade

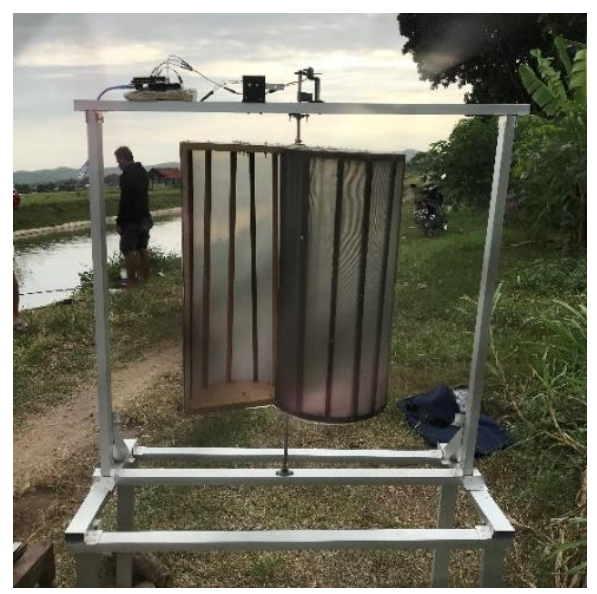

Fig. 11. Implementation of Single-level Savonius Wind Turbine.

The plates of the Savonius wind turbine blades are made using round MDF wood with a diameter of $300 \mathrm{~mm}$. Round MDF woodcut in half so that it forms a semicircle. The ribs from the blade are made using wood with dimensions of $10 \times 10 \mathrm{~mm}$, which has a height of $600 \mathrm{~mm}$. The blade of the turbine is made using fiber material. Acrylic on the blade is used to join the two parts of the blade so that the blade shape of the Savonius wind turbine is in the shape of the letter S.

\section{B. Implementation of Multi-level Savonius Wind Turbine with Fixed Rotational Axis}

Figures 12 and 13 show the result of the blade and the implementation of a multi-level Savonius wind turbine with a fixed rotational axis. 


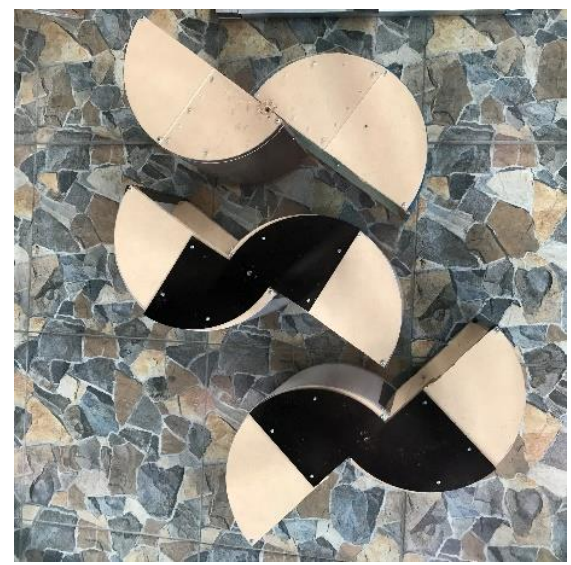

Fig. 12. Multi-level Savonius Wind Turbine with Fixed Rotational Axis Blade

As shown in Figure 12, the plate used on the blades used the same material as a single-level Savonius wind turbine, which is MDF wood with $300 \mathrm{~mm}$ in diameter and $15 \mathrm{~mm}$ thick. The blade's frame is made with wood that has dimensions of $10 \times 10 \mathrm{~mm}$ and a height of $200 \mathrm{~mm}$. There are three pairs of blades used to make the multi-level Savonius wind turbine with a fixed rotational axis.

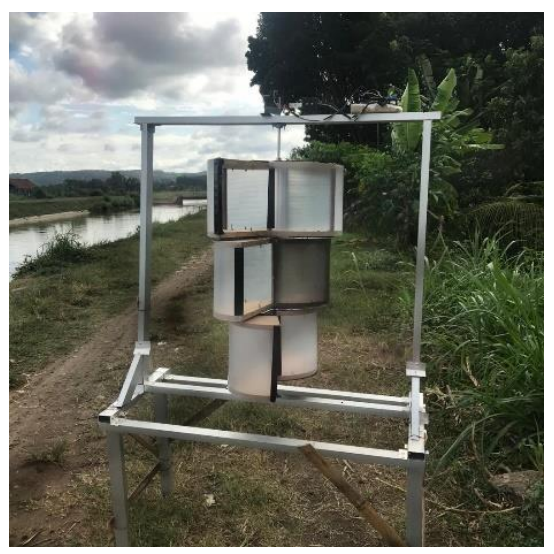

Fig. 13. Multi-level Savonius Wind Turbine with Fixed Rotational Axis

The implementation of a multi-level wind turbine with a fixed rotational axis is shown in Figure 13. There are three pairs of blades turbine mounted on a shaft with a diameter of $8 \mathrm{~mm}$ and a height of $1000 \mathrm{~mm}$. The blades are installed not to rotate independently, which means if one blade rotates, then all the blades rotate. This is done by attaching the adapter shaft connector to the blade plate's surface at the top level and the lowest level so that the blade automatically will rotate independently. At each level of turbine blades, The winds of Savonius are terraced with a fixed rotating axis. There is a difference in the horizontal angle of 30 degrees so that at the top level has a difference of the blade with a base level of 60 degrees.

\section{Implementation of Multi-level Savonius Wind Turbine with Independent Rotational Axis}

Figure 14 shows the implementation of a multi-level Savonius wind turbine with an independent rotational axis.

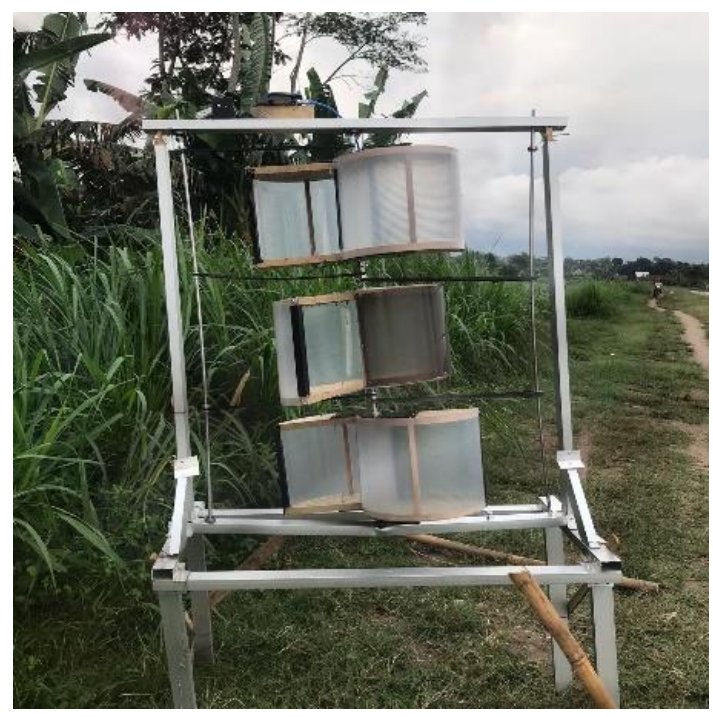

Fig. 14. Multi-level Savonius Wind Turbine with Independent Rotational Axis

Blades used on a multi-level Savonius wind turbine with an independent rotational axis are the same as the blade used on a multi-level wind turbine with the fixed rotational axis. Based on Figure 14, three pairs of blades turbines mounted on shafts with a diameter of $5 \mathrm{~mm}$ and a height of $1000 \mathrm{~mm}$. The blades are installed so that they can rotate independently, which means that each level of the blade does not depend on each other to rotate individually.

\section{Measurement Result of Angular Speed, Torque, and Power}

Figure 15 shows a comparison of measurement results from the Savonius wind turbine angular speed value. 


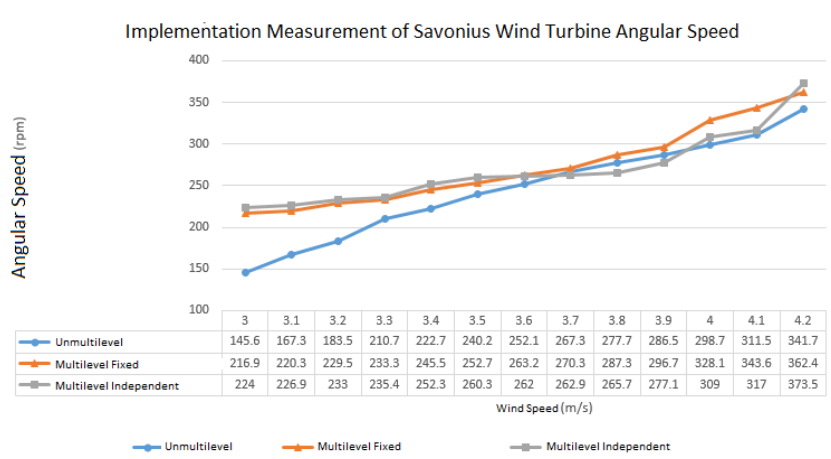

Fig. 15. Implementation measurement of Savonius Wind Turbine Angular Speed

The multi-level Savonius wind turbine with a fixed rotational axis has the highest average angular speed value equal to 273.06rpm. In comparison, the single-level Savonius wind turbine has the average value that equal to $246.57 \mathrm{rpm}$, and multi-level Savonius wind turbine with independent rotational axis $269.16 \mathrm{rpm}$.

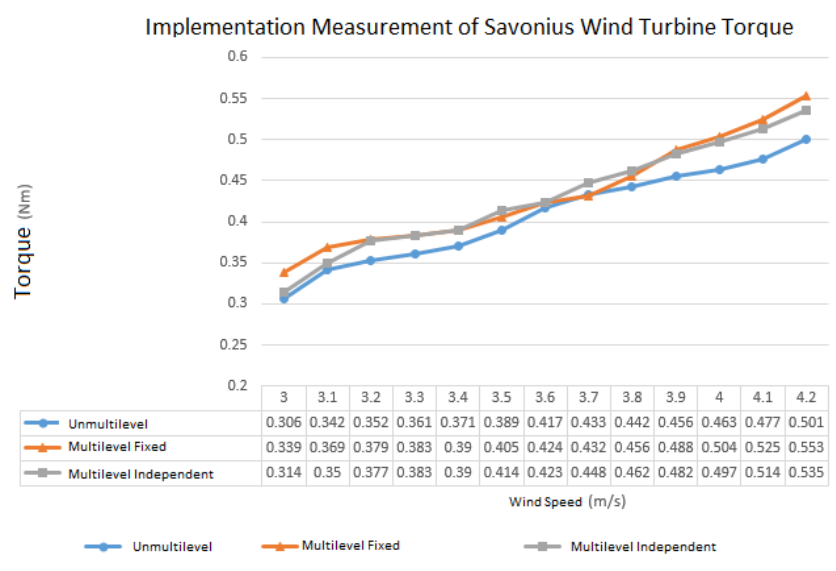

Fig. 16. Implementation Measurement of Savonius Wind Turbine Torque

Based on the graphic in Figure 16, the multi-level Savonius wind turbine with a fixed rotational axis has the highest average torque value with $0.434 \mathrm{Nm}$. In contrast, the singlelevel Savonius wind turbine has an average torque value that equals $0.408 \mathrm{Nm}$. The multi-level Savonius wind turbine with an independent rotational axis has an average torque value that is $0.423 \mathrm{Nm}$.

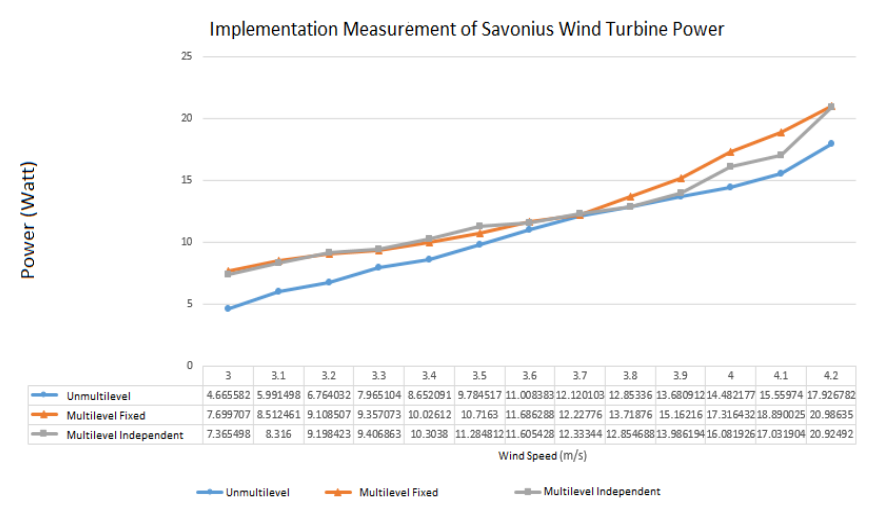

Fig. 17. Implementation measurement of Savonius Wind Turbine Power

Based on the graphic from Figure 17, the multi-level Savonius wind turbine with a fixed rotational axis has the highest average power value equal to 12.72 Watt. In comparison, the single-level Savonius wind turbine has the average value that equal to 10.88 Watt and the multi-level Savonius wind turbine with independent rotational axis $12.36 \mathrm{Watt}$

\section{CONCLUSION}

Based on the measurement on the real implementation, multilevel Savonius wind turbine with a fixed rotational axis has the highest performance with an average angular speed value 273.06rpm, average torque value $0.434 \mathrm{Nm}$, and average power value $12.72 \mathrm{Watt}$.

\section{REFERENCE}

[1] Asif M, Muneer T. Energy supply, its demand and security issues for developed and emerging economies. Renewable and Sustainable Energy Reviews, 2007;11:1388-413.

[2] Ahmad AL, Yasin NHM, Derek CJC, Lim JK. Microalgae as a sustainable energy source for biodiesel production: a review. Renewable and Sustainable Energy Reviews, 2011;15:584-93.

[3] I.E. Agency. World energy outlook. Paris: International Energy Agency; 2009.

[4] Hasan, M. H., Mahlia, T. M. I., Nur, H. (2012). A review on energy scenario and sustainable energy in Indonesia. Renewable and Sustainable Energy Reviews, 16(4), 2316-2328.

[5] Sopian MYOK, Yatim B, Daud WRW. Future directions in Malaysian environment friendly renewable energy technologies research and development. ISESCO, Science and Technology Vision 2005;1:30-6.

[6] Direktorat Jenderal Ketenagalistrikan, Statistik Ketenagalistrikan Tahun 2018, Sekretariat Jenderal Ketenagalistrikan: 2019 
[7] BMKG, Kecepatan Angin dan Kelembaban Udara di Stasiun Pengamatan BMKG, 2011-2015. Badan Pusat Statistika: 2017.

[8] Isemer, H.J. and L. Hasse, 1991: The Scientific Beaufort Equivalent Scale: Effects on Wind Statistics and Climatological Air-Sea Flux Estimates in the North Atlantic Ocean. J. Climate, 4, 819-836.

[9] Arismunandar Wiranto. Penggerak mula: Turbin, Edisi ketiga cetakan satu. Bandung: Penerbit ITB, 2004.

[10] Indonesia energy outlook statistic 2006. Depok, Indonesia: Energy Reviewer, University of Indonesia; 2006.

[11] Mohammed Hadi Ali, Experimental Comparison Study for Savonius Wind Turbine of Two Three Blades At Low Wind Speed, International Journal of Modern Engineering Research (IJMER):2013

[12] Marvin T, Bagus A, Levin H. Power Coefficient Performance of Savonius Wind Turbine Using CFD Analysis. International Conference on Mechatronics, Robotics, and Systems Engineering (MoRSE), 2019. 